\title{
The state of the Association
}

\author{
By JoAn S. Segal \\ Executive Director \\ Association of College \& Research Libraries
}

\section{The Executive Director's report for 1987/1988.}

\begin{abstract}
A
s I begin my fifth year at ACRL, I am pleased to be able to describe here an Association with a stable structure and membership, burgeoning programs, an active planning and implementation process leading to the attainment of goals set out by the members, and strong financial and human resources.
\end{abstract}

\section{Structure}

ACRL has 41 standing and ad hoc committees, editorial boards and task forces; 14 sections; 15 discussion groups; 39 chapters; and a total of 163 subcommittees. During the triennial review process, the Planning Committee considers all standing committees and sections, their charges, activities, and future plans.

Ad hoc committees and task forces are regularly formed and discharged as their tasks are accomplished. At present, the structure seems to be working well and is stable, with the needed flexibility provided by these time-limited options.

\section{Program}

I will again report ACRL program accomplishments in terms of our major goals.

Goal 1. To contribute to the total professional development of academic and research librarians.

ACRL's local education presentations in 24 locations reached 825 people this year, while 163 participated in the courses at New Orleans. The development and offering of new courses is now an ongoing process based on regular membership and course evaluations and is handled by the Course
Advisory Committee, with Sandy Donnelly serving as staff. Alia Al-Taqi handles local presentations.

This was a year for educational innovations in ACRL. Our first overseas conference was held in Florence, Italy, April 5-8, by the Western European Specialists Section. "Shared Resources, Shared Responsibilities" was the conference theme and also the motto of the organizing committee, headed by Assunta Pisani, chair, and Mario Casalini, local arrangements head. 170 participants, 80 from outside the U.S., enjoyed a variety of sessions and opportunities to meet their library, information center, and publishing industry colleagues.

Another first was the CJCLS CD-ROM Teleconference, also held in April. This high-interest topic, coupled with low-cost accessibility, resulted in an estimated audience of 10,000-11,000 viewers.

At New Orleans, RBMS held its 29th Preconference: "Librarians and Museums: Leaves from Each Other's Books." The Bibliographic Instruction Section held a 3d Preconference, "The Future of BI: Approaches in the Electronic Age." Both attracted large audiences. Mary Ellen Davis assisted as staff liaison for these preconferences.

RBMS is planning a one-day preconference in Dallas, and has begun work on its Fall 1989 Conference in Cambridge, England, on the theme, "The Antiquarian Book Trade."

Another important aspect of professional development is career development. Through some 750 classified ads in $C \& R L N e w s$, publication of the Fast Job Listing Service, and maintenance of the ACRL Jobline, ACRL helps both academic li- 
braries and librarians meet their staffing needs.

Awards, whereby we recognize our peers for their accomplishment, constitute yet another mode of professional development. During 1988 the Awards Task Force examined ACRL's awards; their report will be considered by the Executive Committee this Fall. Mary Ellen Davis is the staff awards liaison.

Goal 2. To enhance the capability of academic and research libraries to serve the needs of users.

Two major program activities under this goal have been the Output Measures Project and the Historically Black College and University library activities.

After careful preparation by the ad hoc Committee on Performance Measures, an RFP was prepared and circulated for a Manual of Output Measures for Academic Libraries. Nancy Van House, University of California, Berkeley, submitted the successful proposal, a contract was negotiated, and work has begun on the project. The measures have been pilot tested, and the manual will be completed, field tested, and ready for publication by this time next year. Mary Ellen Davis has been staff liaison to the Committee.

The Mellon Foundation funded a gathering of 30 librarians from Historically Black Colleges and Universities (HBCU's) in Atlanta in October. There the participants identified three projects for ACRL to pursue: a statistics-gathering activity, workshops for librarians in institutions undergoing accreditation (especially under the new criteria of the Southern Association of Colleges and Schools) and a humanities workshop targeted at HBCU's and their communities. Preparatory work was undertaken in all three areas during 1988. In the 1989 fiscal year, the Committee will take on the statistics project and an accreditation preconference and an $\mathrm{NEH}$-funded humanities programming workshop will be held.

Advisory services are designed to provide assistance to those who call or write us with questions about academic libraries and librarianship. In fiscal year 1988, we answered over 250 such questions. Although all staff are involved in this function, Mary Ellen Davis is the staff member with major responsibility here.

In addition, work is proceeding on the University Library Standards and on the ACRL/AECT Joint Standards for Libraries in Two-year Institutions. Development of an accreditation manual is underway to help librarians play a more effective role in accreditation of their institutions.

All through the year, C\&RL News continued to carry articles inspired by Joanne Euster's theme of creativity. The "Innovations" section of each issue has featured outstanding examples of new, creative approaches.

Goal 3. To promote and speak for the interests of academic and research librarianship.

The Professional Association Liaison Committee continued its work, funding travel for ten ACRL members to make presentations at non-library meetings and identifying 11 target associations for liaison activity.

The activities of several chapters in recruitment were very exciting. Members visited library schools, took booths at career fairs, offered scholarships, gave students special rates for events, all to encourage young people to enter the academic library profession. Alia Al-Taqi is the staff chapter liaison.

The Legislation Committee cooperated with the ALA Washington Office on NTIS privatization, funding for both LSCA and HEA, and many other issues. Hal Shill's work here was invaluable.

Goal 4. To promote study, research, and publication relevant to academic and research librarianship.

ACRL's active publishing program produced our membership journals, College \& Research Libraries and College of Research Libraries News. Rare Books and Manuscripts Librarianship was officially welcomed to the roster of regular publications. Twelve sections issued newsletters, Chapter Topics came out quarterly, and Choice continued to be a major academic library selection tool. George Eberhart and Cheryl Robinson-Smith are responsible for $C \triangleleft R L$ News, $R B M L$, and section newsletters; Alia Al-Taqi edits and distributes Chapter Topics, and Patricia Sabosik, editor and publisher of Choice, heads a staff of 20 in the Middletown, Connecticut, office.

Nonperiodical publications produced in 1988 were:

- Academic Status: Statements and Resources.

- Binding Terms: Thesaurus for Use in Rare Book and Special Collections Cataloguing.

- Provenance Evidence: Thesaurus for Use in Rare Books and Special Collections Cataloguing.

- Your Old Books.

- Friends of College Libraries: CLIP Note \#9.

- Annual Reports in College Libraries: CLIP Note \#10.

- English and American Literature: Sources and Strategies for Collection Development, Publications in Librarianship, no. 45.

A major accomplishment for 1988 was the publication of the third edition of Books for College Libraries. Long a standard reference work in academic librarianship, the second edition had gone out of date and a new one was sorely needed. Subsidized by funds from ACRL's reserve, the editorial work ran to some $\$ 150,000$ over three fiscal years. This is in addition to a similar amount invested by ALA Publishing in production costs. It is highly unlikely that sales of the work, published jointly by ALA and ACRL, will be sufficient to recover these costs in full. Use of technology also enables us to distribute the work as a tape product, an online service and, possibly, in another alternative format. Pat Sabosik was project officer on BCL3. 


\section{Planning at ACRL}

With each passing year, we enhance the process begun in 1984 , to use planning as a way to make ACRL responsive to members' needs. After assessing needs in 1985, developing, refining, and officially adopting a mission statement, goals, objectives, and strategies in 1986, and beginning to implement the plan in 1987, ACRL leaders and staff have started to establish mechanisms for annual planning, for reporting on the accomplishment of planned objectives, for tying in allocation of resources more closely to the plan, and for involving members at all levels in updating the plan for the future.

The Planning Committee, under Carolyn Dusenbury's guidance, has developed new means for communicating with ACRL units, combining multiple information requests in an effort to encourage participation.

During 1988 the ACRL Board set its priorities for 1989 and 1990, and adopted an Operating Plan for 1989, its first ever. In New Orleans, the President-Elect for 1990, Bill Moffett, was able to participate actively in the priority-setting process.

Also new is a long-range financial plan, now under development, which will allow ACRL to provide for the financial undergirdings of its ambitious program plans. The Financial Plan is in its second draft and will be ready for member hearings and Board approval during the 1989 fiscal year.

\section{Membership and finance}

At $\$ 25$, membership in ACRL is a bargain, as other divisions begin to increase dues to $\$ 30$ (LAMA, ALTA) \$35 (PLA) and more (ASCLA State Library Memberships are \$500). The extent of the bargain is even greater when the active program of professional development, publication, and service are taken into account.

In line with developments in association management, ACRL and many other parts of ALA have moved over the past 10 years to establish nondues sources of revenue, so as to "stretch" the dues dollar and also to place the burden of specific services on their users. For instance, divisional National Conferences, continuing education courses, and publications have been priced to be selfsupporting. There are obvious advantages to such methods of financing an association. An interesting corollary is that, as the total budget grows very large with these revenues and expenses, the proportion of the budget coming from dues decreases. Thus, in 1988-89, dues will constitute only about $23.3 \%$ of the total revenue. Another $32.8 \%$ will come from educational activities, including the Cincinnati Conference; $37.3 \%$ from publications (not including Choice), and 5.6\% from outside funding for projects.

One way of looking at this is to say that membership is even more of a bargain; with only $\$ 250,000$ in dues revenue, we run a $\$ 2.5$ million dollar association. However, it also means we need to be very clear about what the dues dollar buys.

Since the ACRL budget is accounted for on the basis of projects, with expenses-including salaries, supplies, and other "indirect" costs allocated to each project on the basis of actual use, it is possible for us to identify the activities that are selfsupporting, those that are supported by grants and other outside funding, those that are supported by dues, and those that draw on our reserves.

While individual publication and education projects do not always break even, our overall publication and education activities are selfsupporting. Funded projects usually require some contribution from dues or reserves, but not a major investment.

Dues support the activities (including staff time) of sections, committees, chapters, and discussion groups, statistics projects, the Jobline, Board and Executive Committee activity, advisory services, awards, membership recruitment, and free distribution of standards.

Over the past 6-8 years, ACRL acquired a sizable "fund balance." In 1986, the ACRL Board decided this should not exceed 6 months' expenses. Such a reserve would allow us to weather a serious financial or membership crisis or provide security against failure of a major event, such as a national conference. Between 1985 and 1989, the Board elected to use reserve funds for several major projects it could not have carried out without those monies. These included Books for College Libraries, 3d edition; the Manual of Output Measures for Academic Libraries; a gift to help establish the Hugh Atkinson Memorial Award, and a Special Grants Fund, which will be operative in any year when there is a reserve fund greater than $50 \%$ of the average annual expenses over the previous 3 years. As we begin the 1989 fiscal year, ACRL's fund balance is just at the 6-month reserve level.

When members join ACRL, they receive $C \triangleleft R L$ News and $C \triangleleft R L$ and reduced rates on other publications and education activities. But most importantly, they receive the benefit of membership itself. Only members may serve on committees and task forces, be active in sections and discussion groups, be elected to office, and share in the decisions that have made ACRL a premier association, the organization that speaks for and serves academic libraries, librarians, and librarianship. Only members have a say in how the ACRL dollars-be they dues or other sources-are allocated.

Membership always increases in a Conference year. As our Cincinnati Conference approaches, heralding 100 years of academic librarians in ALA, 50 years of ACRL's existence and that of $C \triangleleft R L$ and C $\triangleleft R L$ News, 25 years of Choice, and our 5th National Conference, we will probably attract some new members. Our task is to keep them interested and eager to remain among us, to involve 
them in the many projects and activities of the Association.

\section{Staffing}

Over the past 5 years, ACRL staff has remained at 10-11 FTE, while the number of new projects has continued to increase. Our staff is relatively stable, with low turnover. The use of office automation has probably contributed to the capacity for taking on additional projects and has definitely begun to save money in design costs as electronic publishing has gradually been implemented.

In FY 1988, Beverley Washington replaced Karen Duhart as Cathleen Bourdon's administrative secretary and Cheryl Robinson-Smith became as- sistant editor of $C \triangleleft R L$ News when Gus Friedlander returned to graduate school. Sandy Donnelly's status changed from full-time employee to parttime consultant.

\section{Summary}

As we begin our fiftieth year, ACRL is an association with a bias for action through a program of publications, educational activities and other projects directed toward goals set by members. Management is also strong, with a good financial strategy and a stable structure and valuable human resources, including committed volunteer members and a capable staff.

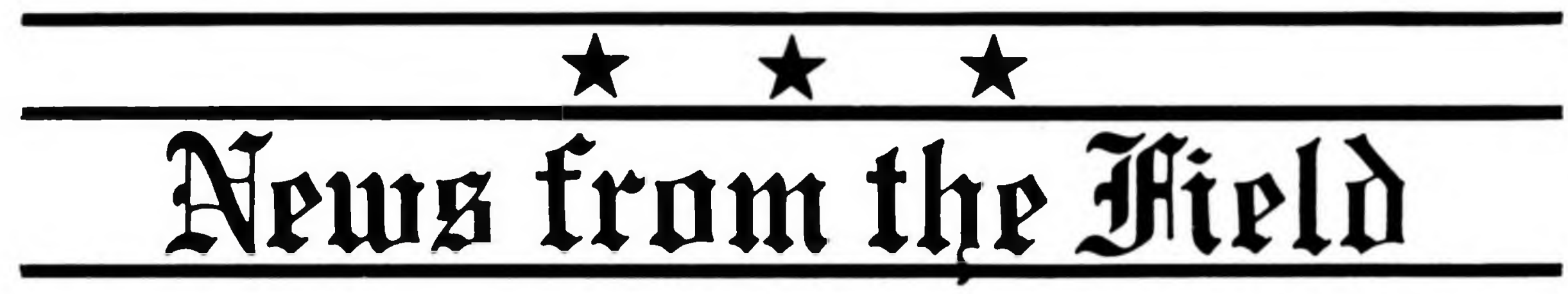

\section{Acquisitions}

- Cornell University Libraries, Ithaca, New York, has received a 143-volume collection of books about the history and design of lace. The books are from the collection of Elizabeth Kackenmeister of Williamsport, Pennsylvania, who died last year. Among the donated volumes are books tracing the development of a cottage industry around lace making and the changing designs and patterns of lace.

- George Washington University's Gelman Library, Washington, D.C., has received a collection of 1,000 Chinese-language books from Chinese Ambassador $\mathrm{Han} \mathrm{Xu}$. The collection was donated by the State Education Commission of the People's Republic of China. The gift includes a variety of works in politics, economics, education, the arts, geography and history.

- The Library of Congress' Music Division, Washington, D.C., has received the largest composite gift of music materials in the division's history. It consists of a large quantity of autograph music manuscripts, letters, and documents spanning the history of musical creativity from the 12th century to modern times. The gift will become part of the Moldenhauer Archives at the Library of Congress. The archives were established in April 1987 by an earlier gift from Hans Moldenhauer, the renowned pianist and author who died in October 1987 , and were previously supplemented with major manuscripts of Johannes Brahms acquired in 1988 from Mary Moldenhauer, his widow. With this bequest, Moldenhauer also established the
Moldenhauer Archives Foundation at the Library of Congress.

-The Massachusetts Institute of Technology Libraries, Cambridge, have received a collection of ten rare early mathematics and mechanics books. The books are the gift of MIT alumnus John D. Stanitz, who for over thirty years worked to build an outstanding collection of historically important works in the areas of solid mechanics, fluid mechanics, mathematics, machinery, and energetics. The collection includes works by Leonard Euler, Niccolo Tartaglia, and Thomas Harriot.

- The Miami University Libraries, Oxford, Ohio, have received the original photographs, drawings, and papers of engineer and explorer Robert Brewster Stanton from his 1889-1890 exploration of the Colorado River. The three and one-half linear feet of materials, including correspondence from William Henry Jackson, Frederick S. Dellenbaugh, and other "men of the West," were used by the donor, Dwight L. Smith, in editing Stanton's diaries and notes for the 1965 book, Down the Colorado. This material, which augments the diaries previously given to the New York Public Library, includes materials given to Smith by Stanton's daughter, Anne Stanton Burchard.

- The Ohio University Libraries, Athens, have received the Sammy Kaye Collection of memorabilia associated with the celebrated bandleader. Kaye (born Sam Zarnocay) graduated from Ohio University in 1932 with a civil engineering degree. The collection includes musical scores and arrangements, broadcast transcripts, phonographs, newspaper clippings, scrapbooks, correspondence, and 